\title{
Erratum to Two Articles in Wireless Personal Communications
}

\author{
Siddig Gomha ${ }^{1}$ Abdel-Aziz T. Shalaby ${ }^{2}$ EL-Sayed M. El-Rabaie ${ }^{2}$ • \\ Ahmed S. Elkorany ${ }^{2} \cdot$ Asmaa $\operatorname{Rady}^{2} \cdot$ Mona Shokair $^{2}$
}

\section{Erratum to: Wireless Pers Commun (2016) 89:331-349 DOI 10.1007/s11277-016-3268-y, 10.1007/s11277-015-2390-6}

In the two published articles listed below, the affiliation of the first author of the second paper was correct, but the other authors' joint affiliation was incorrect. Their affiliation is correct in this erratum.

Rady, A., Shokair, M., El-Rabaie, E.-S.M. \& Elkorany, A.S. (2015) Efficient Technique for Sidelobe Suppression and PAPR Reduction in OFDM-Based Cognitive Radios. Wireless Pers Commun 83, 215-230

Gomha, S., Shalaby, A.-A.T., El-Rabaie, E.-S.M. \& Elkorany, A.S. (2016) Thin Film Ferroelectric Compact Branch-Line Coupler Based on D-CRLH Unit Cell and YBCO HTS Microstrip. Wireless Pers Commun 89, 331-349

The online versions of the original articles can be found under doi:10.1007/s11277-016-3268-y, 10.1007/ s11277-015-2390-6.

Siddig Gomha

siddig.gomha@gmail.com

$\triangle$ Ahmed S. Elkorany

elkoranyahmed@yahoo.com

1 Faculty of Engineering, University of Medical Sciences and Technology, P.O. Box 12810, Khartoum, Sudan

2 Department of Electronics and Electrical Communications Engineering, Faculty of Electronic Engineering, Menoufia University, Menouf 32952, Egypt 